\title{
Teachers' Beliefs about the Impact of Students' Peer Correction at Post-Writing Stage on Letter Writing
}

\author{
ToanBao Nguyen, HuanBuu Nguyen \\ Can Tho University, Vietnam
}

\begin{abstract}
This paper reports a descriptive study to examine English as a Foreign Language (EFL) teachers beliefs about the impact of students' peer correction at the post-writing stage (PWS) on students' writing performance in letter writing. This paper draws on data collected as part of a larger project including questionnaire and semiinterviews. The findings reveal that teachers held positive beliefs about the impact of students' peer correction on students' letter writing performance. Implications for practical applications of students' peer correction are also presented.
\end{abstract}

Keywords: beliefs, peer correction, letter writing, post-writing stage

\section{Introduction}

Research into peer correction has addressed its role and positive impact on student writing for the past few decades. Due to its facilitative function in improving student writing, peer feedback has become increasingly popular in second and foreign language writing classes(Fan \& Xu, 2020). While the findings of previous research have shed some light on the aspects of student engagement with peer feedback (e.g., Fan \& Xu, 2020; H. T. Nguyen, 2016), learners' attitudes(Pham, 2015), the effects of peer correction(Behin \& Hamidi, 2011; Cao, 2012), little research has been done to investigate teachers' beliefs about students' peer correction at postwriting stage in letter writing, especially, in the teaching and learning contexts in the Mekong delta, Vietnam. This present study, therefore, fills the gap.

The research question that guided the study reported on in this paper was: "What are teachers' beliefs about the impact of students' peer correction at the post-writing stage on students' writing performance in letter writing?"

\section{Literature review}

\subsection{Teachers' beliefs}

As the term 'beliefs' has been defined in several studies with different meanings for several years (e.g., Fives \& Gill, 2015; Pajares, 1992; Rokeach, 1968), it is essential to understand what teachers' beliefs are and how they influence teachers' making-decision in their teaching practices.

Rokeach (1968) defines beliefs as "any simple proposition, conscious or unconscious, inferred from what a person says or does, capable of being preceded by the phrase 'I believe that...'” (p.113). In his view, teachers' beliefs are associated with drawing inferences about their attitudes and sets of value (Seidman, 2004) from a continuum of their saying, intentions, and actions (Pajares, 1992). Thus, beliefs involve a repertoire of opinions gleaned and developed from an individual as a result of his experiences and thinking process. As a matter of fact, different teachers hold different beliefs or views, teacher beliefs are more influential than experience in various ways of designing lesson plans or making decisions in teaching practices (Pajares, 1992). In other words, teacher beliefs are likely to influence their thinking about their actions, thereby resulting in tailoring their instructional strategies and shifting their roles to improve their existing practices (e.g., H. B. Nguyen, 2013, 2019).However, at the time of this study, there have not been any studies that examined teacher beliefs about peer correction on students' letter writing in the teaching and learning of writing in Vietnamese context. It is therefore important to examine the role of teacher beliefs in their practice of peer correction at the post-writing stage on students' letter writing performance. For the purposes of this current study, the term "beliefs" refers to teachers' thinking about what they are going to do in improving their practices. 
DOI: $\underline{10.51386 / 25815946 / i j s m s-v 4 i 3 p 112}$

Volume: 4 Issue: 3

May to June 2021

www.ijsmsjournal.org

\subsection{Peer correction}

Peer correction is a form of feedback that has attracted much attention from English language teaching and learning in recent years. Peer correction is known by a number of names, including peer response, peer feedback, peer review and peer editing (Bijami, Kashef, \& Nejad, 2013). In this article, the terms 'peer correction' and 'peer feedback' are interchangeably used. In their comprehensive book on peer feedback, Liu and Hansen (2002) define peer feedback as:

the use of learner as source of information; and interactant for each other in such a way that learner assume roles and responsibility generally taken on by a formally trained teachers, tutor or editor in commenting on and critiquing each other's drafts in both written and oral formats in process of writing(p.1)

Research in tertiary education has indicated that peer feedback was perceived by students as more plausible and helpful since peers share similar views and organize a particular writing task collectively (Gielen, Tops, Dochy, Onghena, \& Smeets, 2010; Topping, 2003). Similarly, Trahasch (2004)contends that peer feedback is a type of collaborative learning in which students learn to interpret and provide positive feedback on the written works of their peers. Peer correctionis seen as a collaborative activity in which students read, criticize and provide correction on the other's writing to promote writing skills(Hyland, 2005; Wahyuni, 2018).

Within the scope of this research, peer correction is a response activity in which students act as evaluators to share writings and review each other's works through pair or group work in order to refine their writing assignments for the quality content.

In the second language learning process, the significance of offering feedback on the writing of learners cannot be denied. Recent research studies have indicated that peer feedback or correction had a positive impact on or could enhance students' writing ability(Min, 2006; Wahyuni, 2018). Another claim in favor of peer correction is that it focuses a lot on the contribution of learners to the learning process sincethe student-centered approach can be encouraged(Sultana, 2009). Thus, peer correction can engage students in writing, which yields the potential to improve students' writing skills. A study by Yang (2010) reveals that peer correction empowers students to monitor, review and edit their texts to enhance their writing. Furthermore, students can sharpen their thinking abilities through this technique, exchange experiences and knowledge, use the target language to edit what they write to develop their self-editing abilities and become more independent learners in the future (Kunwongse, 2013) or tend to be inherently inspired or motivated(Wahyuni, 2018).

Despite the perceived benefits, peer correction may have several challenges. First of all, peer correction is timeconsuming, especially when students are not familiar with the process (Rollinson, 2005). Secondly, students prefer teachers' feedback to their peers'for different reasons such as lack of confidence in their peers, being aware of their own linguistics limitations (Hyland \& Hyland, 2006). The third argument against peer correction or peer feedback is that some students may not value the correction provided by their peers due to a lack of confidence in their peers' ability to provide constructive input, or fail to provide feedback in their revisions (Ferris, 2002; Gielen et al., 2010; Nelson \& Murphy, 1993).

\subsection{Writing and letter writing}

\subsubsection{Writing}

Writing skill has been considered one of the most difficultskills of English for learners to master, particularly in an English as a foreign language (EFL) context (Richards \& Renandya, 2002). Writing is a set of letters or symbols written or marked on a surface as a means of communication(Geyte, 2013; Harmer, 2007). This view suggests that writing is the communicative process of creating a piece of written language designed to be read. A similar argument for this is that writing is the product of a language user's information perspective and communicative competence(Schmitt, 2010). Although writing is considered as a complex and difficult skill for learners to pick up, Rivers (2018) claims that writing is the expression of ideas in a systematic way to organize the graphic conventions of the language. Taken all above-mentioned views together, writing is viewed as a sophisticated process that involves an individual's activity to communicate and make sense of ideas to intended audience. Thus, writing plays a key position in English language teaching and learning. 
DOI: $\underline{10.51386 / 25815946 / i j s m s-v 4 i 3 p 112}$

Volume: 4 Issue: 3

May to June 2021

www.ijsmsjournal.org

\subsubsection{Letter writing}

As letters are common forms of a given text, letter writing either formal or informal, refers to most popularly used forms of writing conveying and communicating ideas or messages from one to another as a social practice (Barton \& Hall, 2000). Barton and Hall(2000)further address that:

letter writing is a static process that examines texts, activities and social contexts, which is used to mediate human interactions and through letters individuals can share experiences, argue views, explain, and describe phenomenon.

This implies that letter writing as embedded in specific social contexts or situations serve a wide array of functions, which involve interpersonally constructed writing activities.

\section{The study}

In order to investigate teachers' beliefs about students' peer correction of post-writing stage on letter writing, a mixed-methods design was used in this study. The mixed-methods design which involvesquantitative and qualitative approaches can provide an opportunity to gain in-depth understanding of a particular topic under investigation (Creswell, 2014; Fraenkel, Wallen, \& Hyun, 2012). For the quantitative approach, a questionnaire was adapted from Jamoom(2016) Teacher Questionnaire. There were 29closed-ended questions on the threesection questionnaire. The first section focuses on teachers' demographic information regarding gender, age, and years of teaching experience and workplace. The second section is teachers' understanding of peer correction concepts and its importance for students' writing. The third section concentrates on teachers' beliefs about the impact of students' peer correction at the post-writing stage on students' writing performance. To complement the quantitative data, semi-structured interviews were conducted with six participating teachers individually at the tenth week of the study. The interview questions were divided into two clusters: teachers' understandings of peer correction and its importance; and teachers' beliefs about the impact of peer correction at the post-writing stage on students' letter writing performance.

Participants in this study were 95 EFL teachers from high schools, foreign language centers and college as well as universities in Mekong Delta. They were selected on the basis of convenience sampling (Fraenkel et al., 2012).Of this sample, 20 teachers $(21.1 \%)$ were males and 75 teachers $(78.9 \%)$ were females. At the time of the study, the number of years they taught ranges less than 1 year $(n=4)$ making up $4.2 \%$, from 1 year to 5 years $(n=44)$ accounting for $46.3 \%$ of participants, 6 to 10 years $(n=17)$ constituting $17.9 \%$, and more than 10 years $(n=30)$ accounting for $31.6 \%$.

All of the survey questions were read and checked by the supervisor and thenpiloted to ensure the reliability of this investigative tool. Twenty-one EFL teachers werechosen to participate in the pilot in the first week of the study. The Cronbach's alpha for the pilot .896 indicates the high reliability of the questionnaire for data collection.Concurrently, the responses and feedback received from the participants in the pilotinterviews allowed for the clarity of the questions, the length of time spent in theprocess, and modifications with regard to the content and sequence in preparation for the actual interviews.

The quantitative data collected from the questionnaire were statistically analyzedusing the computer software Statistical Package for the Social Sciences (SPSS) version 20. The interview responses were handcoded, transcribed, and then translated intoEnglish. Analysis of the interviews was based on identifying the themes (Boyatzis, 1998)emergedthrough the interview process.

\section{Findings}

This section presents the findings of the study with regard to teachers' beliefsabout the impact of peer correction on students' letter writing performance. The findings reveal that all teachersin this study acknowledged the importance of peer correction for students' writing, andheld positive beliefs about the impact of students' peer correction on students' letter writing performance. 
DOI: $\underline{10.51386 / 25815946 / i j s m s-v 4 i 3 p 112}$

Volume: 4 Issue: 3

\subsection{Findings from the questionnaire}

\subsubsection{Teachers' understanding of peer correction and its importance}

Section Two of the questionnaire of eight items presents teachers' understanding of students' peer correction and its importance to students' writing, as shown in Table 4.1.

Table 4.1 Teachers' understanding of students' peer correction and its importance

\begin{tabular}{|c|c|c|c|c|c|c|}
\hline & \multicolumn{2}{|c|}{ SD \& D } & \multicolumn{2}{|l|}{$\mathbf{N}$} & \multicolumn{2}{|c|}{ SA \& A } \\
\hline Items & $\mathrm{F}$ & $\mathrm{P} \%$ & $\mathrm{~F}$ & $\mathrm{P} \%$ & $\mathrm{~F}$ & $\mathrm{P} \%$ \\
\hline $\begin{array}{l}\text { 1. Students' peer correction is an activity which students read, } \\
\text { criticize and give comments on their friend's writing. }\end{array}$ & 3 & 3.2 & 3 & 3.2 & 89 & 93.6 \\
\hline $\begin{array}{l}\text { 2. Students' peer correction is the input which peer readers } \\
\text { give the writers to help the latter revise their written work. }\end{array}$ & 2 & 2.1 & 16 & 16.8 & 77 & 81.1 \\
\hline $\begin{array}{l}\text { 3. Students' peer correction plays a vital role in stimulating } \\
\text { students' participation in writing }\end{array}$ & 6 & 6.3 & 20 & 21.1 & 69 & 72.6 \\
\hline $\begin{array}{l}\text { 4. Students' peer correction allows learners to consider their } \\
\text { writing level. }\end{array}$ & 7 & 7.4 & 17 & 17.9 & 71 & 74.7 \\
\hline 5. Students' peer correction is useful for students' writing. & 10 & 10.5 & 7 & 7.4 & 78 & 82.1 \\
\hline $\begin{array}{l}\text { 6. Students' peer correction helps students to improve their } \\
\text { own writing skills. }\end{array}$ & 1 & 1.1 & 11 & 11.6 & 83 & 87.3 \\
\hline $\begin{array}{l}\text { 7. Students' peer correction helps students sharpen their } \\
\text { critical thinking ability in their writing. }\end{array}$ & 2 & 2.1 & 8 & 8.4 & 85 & 89.5 \\
\hline $\begin{array}{l}\text { 8. Students' peer correction helps students become more } \\
\text { autonomous writers. }\end{array}$ & 3 & 3.1 & 21 & 22.1 & 71 & 74.8 \\
\hline
\end{tabular}

Note: $\quad \mathbf{F}=$ Frequency;P=Percentage;SD\&D=Strongly disagree $\quad \& \quad$ disagree; $\quad \mathbf{N}=$ Neutral; $\quad \mathbf{S A} \& \mathbf{A}=$ Strongly agree \& agree

As can be seen from Table 4.1, almost all of the teachers (93.6\%) agreed that students' peer correction is an activity in which students read, criticize and give comments on their peer's writing performance $(n=89) .82 .1 \%$ of the participants $(n=78)$ agreed that students' peer correction is useful for students' writing. $81.1 \%$ of the participants $(n=77)$ affirmed that students' peer correction is consider as the input which peer readers give the writers. Moreover, $72.6 \%$ of participants $(n=69)$ agreed that students' peer correction plays an important role in stimulating students' participation in writing. $74.7 \%$ of the participants $(n=71)$ agreed that students' peer correction allows learners to consider their writing level. In addition, students' peer correction is useful for students' writing, which made up $82.1 \%$ of teachers' agreement degree $(n=78) .87 .3 \%$ of the teachers $(n=83)$ agreed that students' peer correction helps students to improve their own writing skills. Besides, $89.5 \%$ teachers $(n=85)$ agree that students' peer correction helps students sharpen in their critical thinking ability in their writing. $74.8 \%$ teachers $(n=71)$ said that peer correction could help students become more autonomous writers.

\subsubsection{Teachers' beliefs about the impact of students' peer correction at the PWS on students' letter writing performance}

Section Three of the questionnaire consists of 21 items with regard to teachers'beliefs aboutthe impact of students' peer correction at the post-writing stage on students' writing performance in letter writing. The mean score of five clusters of teachers' beliefs about the impact is shown in Table 4.2. 
DOI: $\underline{10.51386 / 25815946 / i j s m s-v 4 i 3 p 112}$

Volume: 4 Issue: 3

May to June 2021

www.ijsmsjournal.org

Table 4.2 Mean score of five clusters of teachers' beliefs about the impact

\begin{tabular}{lccccc}
\hline Clusters & N & Minimum & Maximum & Mean & SD \\
\hline Content & 95 & 2,33 & 5,00 & 3,90 &, 56 \\
\hline Organization & 95 & 2,00 & 5,00 & 3,84 &, 60 \\
\hline Vocabulary & 95 & 2,5 & 5,00 & 3,78 &, 52 \\
\hline Language use & 95 & 2,14 & 5,00 & 3,90 &, 58 \\
\hline Mechanics & 95 & 2,33 & 5,00 & 4,10 &, 66 \\
\hline
\end{tabular}

As can be seen from Table 4.2, the mean scores of five clusters of participants' agreement range from 3.78 to 4.10 , indicating that teachers believed that students' peer correction at the post writing stage impacted on student's writing performance in letter writing. Of the five clusters, teachers' beliefs about the impact of students' peer correction on Mechanicsgot the highest mean score $(M=4.10, S D=.66)$, followed by Language use $(M=3.90, S D=.58)$ and Content $(M=3.90, S D=.56)$. Next, the mean score of Organization got the mean score at the third place $(M=3.84, S D=.60)$. The cluster Vocabulary had the lowest mean score $(M=3.78, S D=.52)$

\section{A. Mechanics}

As shown in Table 4.2, cluster Mechanics took the highest mean score $(M=4.10$, $S D=.66)$. A One - Sample t-Test was conducted to check whether the mean score of the participants' level of beliefs about the impact regarding mechanics is statistically different from the test value of 4.5 , a very high value of agreement. The result shows that a significant difference between the mean score and the test value of 4.5 was observed $(t=-5,85, d f=94, p=.000>.05)$. Therefore, the mean score of the participants' beliefs about the impact of students' peer correction on students' writing performance in term of mechanics was at a high level.

A Frequency Test was computed to examine which items of Mechanicsgained high level of agreement. The result is presented in Table 4.3 below.

Table 4.3 Teachers' beliefs about the impact of students' peer correction at the PWS on mechanics

\begin{tabular}{|c|c|c|c|c|c|c|}
\hline & \multicolumn{2}{|c|}{ SD \& D } & \multicolumn{2}{|l|}{$\mathbf{N}$} & \multicolumn{2}{|c|}{ SA \& A } \\
\hline Items & $\mathrm{F}$ & $\mathrm{P} \%$ & $\mathrm{~F}$ & $\mathrm{P} \%$ & $\mathrm{~F}$ & $\mathrm{P} \%$ \\
\hline $\begin{array}{l}\text { 27. I believe students' peer correction at the PWS } \\
\text { helps students minimize the errors of spelling in } \\
\text { letter writing. }\end{array}$ & 1 & 1.1 & 13 & 13.7 & 81 & 85.2 \\
\hline $\begin{array}{l}\text { 28. I believe students' peer correction at the PWS } \\
\text { helps students minimize the errors of punctuation } \\
\text { in letter writing. }\end{array}$ & 2 & 2.1 & 24 & 25.3 & 69 & 72.6 \\
\hline $\begin{array}{l}\text { 29. I believe students' peer correction at the PWS } \\
\text { helps students minimize the errors of capitalization } \\
\text { in letter writing. }\end{array}$ & 3 & 3.2 & 15 & 15.8 & 77 & 81 \\
\hline
\end{tabular}

As can be seen from Table 4.3, 85.2 \% of the participants $(n=81)$ believed that students' peer correction at the post writing stage helps students minimize the errors of spelling in letter writing. $81 \%$ of the teachers $(n=77)$ believed that students' peer correction at the post-writing stage helps students minimize the errors of capitalization in letter writing. Finally, $72.7 \%$ teachers $(n=69)$ believed that students' peer correction at the post writing stage helps students minimize the errors of punctuation in their letter writing.

B. Content

As shown in Table 4.2, cluster Contentwas in the second place $(M=3.90, S D=.56)$. A One Sample t-Test was conducted to check whether the mean score of the participants' 
DOI: $10.51386 / 25815946 /$ ijsms-v4i3p112

Volume: 4 Issue: 3

May to June 2021

www.ijsmsjournal.org

level of beliefs regarding Contentis statistically different from the test value of 4.5, a high value of agreement. The result shows that a significant difference between the mean score and the test value of 4.5 was observed $(t=-10,38, d f=94, p=.000>.05)$. Therefore, the mean score of the participants' beliefs about the impact of peer correction on the content in letter writing was at a high level.

A Frequency Test was computed to examine which items of the Contentgained high level of agreement. The results are given in Table 4.4.

Table 4.4 Teachers' beliefs about the impact of students' peer correction at the PWS on content

\begin{tabular}{|c|c|c|c|c|c|c|}
\hline & \multicolumn{2}{|c|}{ SD \& D } & \multicolumn{2}{|l|}{$\mathbf{N}$} & \multicolumn{2}{|c|}{ SA \& A } \\
\hline Items & $\mathrm{F}$ & $\mathrm{P} \%$ & $\mathrm{~F}$ & $\mathrm{P} \%$ & $\mathrm{~F}$ & $\mathrm{P} \%$ \\
\hline $\begin{array}{l}\text { 9. I believe students' peer correction at the PWS helps } \\
\text { students complete all the required content points in letter } \\
\text { writing. }\end{array}$ & 8 & 8.4 & 22 & 23.2 & 65 & 68.4 \\
\hline $\begin{array}{l}\text { 10. I believe students' peer correction at the PWS helps } \\
\text { students have more relevant supporting ideas to the topic } \\
\text { in letter writing. }\end{array}$ & 3 & 3.2 & 14 & 14.7 & 78 & 82.1 \\
\hline 11. I believe students' peer correction at the PWS helps & 2 & 2.1 & 15 & 15.8 & 78 & 82.1 \\
\hline
\end{tabular}

Note: $\mathbf{F}=$ Frequency; $\mathbf{P}=$ Percentage $;$ SD \& D = Strongly disagree and disagree; $\mathbf{N}=$ Neutral $; \mathbf{S A} \& \mathbf{A}=$ Strongly agree and agree

As shown in Table 4.4, a majority of teachers $(82.1 \%)$ believed that students' peer correction at the post- writing stage helps students have more relevant supporting ideas to the topic in letter writing, and students can develop the ideas thoroughly in letter writing $(n=78) .68 .4 \%$ of the participants $(n=65)$ believed that this peer correction technique enables students complete all the required content points in letter writing.

\section{Language use}

As indicated in Table 4.2, cluster Language usewas also in the second place $(M=3.90, S D=.58)$. A One Sample tTest was conducted to check whether the mean score of the participants'level of beliefs regarding language use is statistically different from the test value of 4.5 , a very high value of agreement. The result shows that a significant difference between the mean score and the test value of 4.5 was observed $(t=-10,16, d f=94$, $p=.000>.05$ ). Therefore, the mean score of the participants' beliefs about the impact of peer correction on the language use in letter writing was at a high level.

A Frequency Test was computed to examine which items of the Language usegained high level of agreement. The results are given in Table 4.5.

Table 4.5 Teachers' beliefs about the impact of students' peer correction on language use

\begin{tabular}{|c|c|c|c|c|c|c|}
\hline & \multicolumn{2}{|c|}{ SD \& D } & \multicolumn{2}{|l|}{$\mathbf{N}$} & \multicolumn{2}{|c|}{ SA \& A } \\
\hline Items & $\mathrm{F}$ & $\mathrm{P} \%$ & $\mathrm{~F}$ & $\mathrm{P} \%$ & $\mathrm{~F}$ & $\mathrm{P} \%$ \\
\hline $\begin{array}{l}\text { 20. I believe students' peer correction at the PWS helps } \\
\text { students minimize the errors of articles in letter writing. }\end{array}$ & 5 & 5.3 & 30 & 31.6 & 60 & 63.1 \\
\hline $\begin{array}{l}\text { 21. I believe students' peer correction at the PWS helps } \\
\text { students minimize the errors of word order in letter } \\
\text { writing. }\end{array}$ & 3 & 3.2 & 22 & 23.2 & 70 & 73.6 \\
\hline $\begin{array}{l}\text { 22. I believe students' peer correction at the PWS helps } \\
\text { students minimize the errors of rules for verbs in letter } \\
\text { writing. }\end{array}$ & 4 & 4.2 & 19 & 20 & 72 & 75.8 \\
\hline 23. I believe students' peer correction at the PWS helps & 5 & 5.3 & 12 & 12.6 & 78 & 82.1 \\
\hline
\end{tabular}


DOI: $10.51386 / 25815946 /$ ijsms-v4i3p112

Volume: 4 Issue: 3

May to June 2021

www.ijsmsjournal.org

students minimize the errors of pronouns in letter

writing.

24. I believe students' peer correction at the PWS helps students minimize the errors of prepositions in letter writing.

$\begin{aligned} & \text { 25. I believe students' peer correction at the PWS helps } \\ & \text { students minimize the errors of tenses in letter writing. }\end{aligned}$
$\begin{aligned} & \text { 26. I believe students' peer correction at the PWS helps } \\ & \text { students enhance the variety of structures in letter } \\ & \text { writing. }\end{aligned}$

Table 4.5 shows that most of the participants $(82.1 \%)$ believed that students' peer correction at the PWS helps students minimize the errors of pronouns in letter writing $(n=78) .81 .0 \%$ of the teachers $(n=78)$ believed that students' peer correction at the post writing stage helps students minimize the errors of tenses in letter writing. Next, $75.8 \%$ teachers $(n=72)$ believed that students' peer correction at the post writing stage helps students minimize the errors of rules for verbs and repositions in their letter writing. $73.6 \%$ teachers $(n=70)$ held the belief that students' peer correction at the post writing stage helps students minimize the errors of word order in letter writing. $68.4 \%$ teachers $(n=65)$ believed that students' peer correction at the post writing stage helps students enhance the variety of structures in letter writing. The lowest rate $63.1 \%$ of teachers $(n=60)$ believed that students' peer correction at the PWS helps students minimize the errors of articles in letter writing.

\section{Organization}

As shown in Table 4.2, cluster Organizationwas in the third position $(M=3.84, S D=.60)$. A One Sample t-Test was conducted to check whether the mean score of the participants' level of beliefs regarding organization is statistically different from the test value of 4.5. The result shows that the difference between the mean score and the test value of 4.5 was significantly different $(t=-10.62, d f=94, p=.000>.05)$. Therefore, teachers' beliefs of the impact of students' peer correction at the post- writing stage on students' writing performance in letter writing in term of the organization was at a high level.

A Frequency Test was computed to examine which items of the Organizationgained high level of agreement. The results are shown in Table 4.6.

Table 4.6 Teachers' beliefs about the impact of students' peer correction in letter writing

\begin{tabular}{|c|c|c|c|c|c|c|}
\hline & \multicolumn{2}{|c|}{ SD \& D } & \multicolumn{2}{|l|}{$\mathbf{N}$} & \multicolumn{2}{|c|}{$\mathbf{S A} \& \mathbf{A}$} \\
\hline Items & $\mathrm{F}$ & $\mathrm{P} \%$ & $\mathrm{~F}$ & $\mathrm{P} \%$ & $\mathrm{~F}$ & $\mathrm{P} \%$ \\
\hline $\begin{array}{l}\text { 12. I believe students' peer correction at the PWS helps } \\
\text { students paragraph appropriately in letter writing. }\end{array}$ & 6 & 6.3 & 25 & 26.3 & 64 & 67.4 \\
\hline $\begin{array}{l}\text { 13. I believe students' peer correction at the PWS helps } \\
\text { students complete their letter with correct format } \\
\text { including salutation, body, and closing. }\end{array}$ & 5 & 5.3 & 18 & 18.9 & 72 & 75.8 \\
\hline $\begin{array}{l}\text { 14. I believe students' peer correction at the PWS helps } \\
\text { students present the ideas in logical order in letter } \\
\text { writing. }\end{array}$ & 3 & 3.2 & 21 & 22.1 & 71 & 74.7 \\
\hline $\begin{array}{l}\text { 15. I believe students' peer correction at the PWS helps } \\
\text { students state the ideas clearly in letter writing. }\end{array}$ & 6 & 6.4 & 16 & 16.8 & 73 & 76.8 \\
\hline
\end{tabular}

As shown in Table 4.6, teachers' agreement of the three items was relatively high. A great number of teachers $(76.8 \%)$ believed that students' peer correction at the PWS helps students state the ideas clearly in letter writing $(n=73)$. $75.8 \%$ of the teachers $(n=72)$ affirmed that students' peer correction at the PWS helps students complete their letter with correct format including salutation, body and closing. $74.7 \%$ of the participants $(n=71)$ believed that this technique helps students present the ideas in logical order in letter 
DOI: $10.51386 / 25815946 /$ ijsms-v4i3p112

Volume: 4 Issue: 3

May to June 2021

www.ijsmsjournal.org

writing. However, $67.4 \%$ of the participants $(n=64)$ agreed that students' peer correction at the PWS helps students divide the paragraphs appropriately in letter writing, whereas $26.3 \%$ of the participants $(n=25)$ were uncertain about this item.

E. Vocabulary

As shown in Table 4.2, the mean score of cluster Vocabularywas in the lowest place $(M=3.78, S D=.52)$. A $O n e$ Sample t-Test was conducted to check whether the mean score of the participants' level of beliefs about the impact of students' peer correction on students' writing performance regarding vocabulary is statistically different from the test value of 4.5 (at very high level). The result shows that a difference between the mean score and the test value of 4.5 was observed $(t=-13.31, d f=94, p=.000)$. It could be concluded that teachers' beliefs of the impact of students' peer correction at the post-writing stage on students' writing performance in letter writing in term of the vocabulary was at a high level.

A Frequency Test was computed to examine which items of the vocabularygained high level of agreement. The results are given in Table 4.7.

Table 4.7 Teachers' beliefs about the impact of students' peer correction at the PWS on vocabulary

\begin{tabular}{|c|c|c|c|c|c|c|}
\hline & \multicolumn{2}{|c|}{ SD \& D } & \multicolumn{2}{|l|}{$\mathbf{N}$} & \multicolumn{2}{|c|}{$\mathbf{S A} \& \mathbf{A}$} \\
\hline Items & $\mathrm{F}$ & $\mathrm{P} \%$ & $\mathrm{~F}$ & $\mathrm{P} \%$ & $\mathrm{~F}$ & $\mathrm{P} \%$ \\
\hline $\begin{array}{l}\text { 16. I believe students' peer correction at the PWS helps } \\
\text { students widen the range of vocabulary in letter writing. }\end{array}$ & 4 & 4.2 & 19 & 20 & 72 & 75.8 \\
\hline $\begin{array}{l}\text { 17. I believe students' peer correction at the PWS helps } \\
\text { students use idioms correctly in letter writing. }\end{array}$ & 12 & 12.7 & 48 & 50.5 & 35 & 36.8 \\
\hline $\begin{array}{l}\text { 18. I believe students' peer correction at the PWS helps } \\
\text { students minimize the errors of word choice in letter } \\
\text { writing. }\end{array}$ & 1 & 1.1 & 20 & 21.0 & 74 & 77.9 \\
\hline $\begin{array}{l}\text { 19. I believe students' peer correction at the PWS helps } \\
\text { students minimize the errors of word form in letter } \\
\text { writing. }\end{array}$ & 2 & 2.1 & 15 & 15.8 & 78 & 82.1 \\
\hline
\end{tabular}

Table 4.7 shows that $82.1 \%$ of the participants $(n=78)$ reported that students' peer correction at the PWS helps students minimize the errors of word form in letter writing. $77.9 \%$ of the participants $(n=74)$ held the belief that students' peer correction at the PWS helps students minimize the errors of word choice in letter writing. $75.8 \%$ teachers $(n=72)$ believed that students' peer correction at the PWS helps students widen the range of vocabulary in letter writing. Only $36.8 \%$ of the participants $(n=35)$ believed that students' peer correction at the PWS helps students use idioms correctly in letter writing.

\subsection{Findings from interviews}

\subsubsection{Insights into teachers' understanding of students' peer correction and their writing}

Analysis from the interview data reveals that the six participating teachers reported arange of differing beliefs that reflected their understandings of students' peer correction in relation to their writing performance. In particular, six interviewed teachers indicated that they had known the term 'peer correction'before participating in this study. When asked to define peer correction, all of them shared the similar idea. For example:

Peer correction is an activity that students read their friends' writing performance and give feedback as well as correct the errors. (Thuy, interview extract)

Peer correction is an activity that students correct the errors to each other. This activity can be implemented by pair work or group work. (Nhu, interview extract) 
DOI: $10.51386 / 25815946 /$ ijsms-v4i3p112

Volume: 4 Issue: 3

May to June 2021

www.ijsmsjournal.org

When asked about the importance of students' peer correction, all six participating teachersshared that students' peer correction at the post-writing stage played a significant role for student' writing. Their views are illustrated in these following comments:

When students correct in peers, they may avoid the errors that they make in their writing work later. They also can learn new ideas from their friends while correcting their friends' writing. [...] About the atmosphere in the classroom, I believe that it is more interesting because students have a chance to discuss or interact with their friends. [...]Later on, they can become independent learners in their learning process (Thuy, interview extract)

Firstly, I think it helps students to improve their writing skills as well as their writing performance. Students also can reduce the number of errors in their writing work. Secondly, this kind of technique can stimulate students' participation in writing, and enhance their critical thinking, also become an independent writer. (Nhu, interview extract)

I find peer correction is useful, especially in writing. It helps students improve their writing skills. [...] Students feel excited and happy when they correct in peers because they can play a role as a teacher to correct their friend's writing work. Besides, it helps students become more independent. They do not depend much on their teachers. (Kha, interview extract)

\subsubsection{Insights into teachers' beliefs about the impact of peer correction on letter writing}

When asked about their beliefs about the impact of students' peer correction on students' writing performance in letter writing, the participating teachers believed peer correction at PWS was a strategy impacting on five writing aspects: (1) content, (2) organization, (3) language use, (4) vocabulary and (5) mechanics. The five aspects are shown in Table 4.8.

Table 4.8 Teachers' beliefs about the impact of students' peer correction on students' writing

\begin{tabular}{lllllll}
\hline & Teacher 1 & Teacher 2 & Teacher 3 & Teacher 4 & Teacher 5 & Teacher 6 \\
\hline Content & & & $\checkmark$ & & $\checkmark$ \\
\hline Organization & $\checkmark$ & $\checkmark$ & $\checkmark$ & $\checkmark$ & $\checkmark$ & $\checkmark$ \\
\hline Language use & & $\checkmark$ & $\checkmark$ & $\checkmark$ & $\checkmark$ & $\checkmark$ \\
\hline Vocabulary & $\checkmark$ & $\checkmark$ & & $\checkmark$ & $\checkmark$ & $\checkmark$ \\
\hline Mechanics & $\checkmark$ & $\checkmark$ & & $\checkmark$ & \\
\hline
\end{tabular}

\section{A. Content}

Two out of the six participating teachers shared the similar ideas about the impact of students' peer correction on students' writing performance. The two teachers believed that peer correction impacts on the content of letters, as shown in the following extracts.

Some students do not cover all of the required ideas in a letter. For example, a letter has three required ideas, but students just complete two of them. Through peer correction, they know that there is a lack of one idea in their writing. Then they can add this idea into their letter to make it better. (Linh, interview extract)

[...] One more thing is that students can have more ideas about the letter they write. For example, students have main ideas for the letter, but they do not know how to explain or provide more detail information about it. Through this activity, students will learnmore relevant supporting ideas from their friends' letter writing.(Trang, interview extract) 
DOI: $10.51386 / 25815946 /$ ijsms-v4i3p112

Volume: 4 Issue: 3

May to June 2021

www.ijsmsjournal.org

\section{B. Organization}

All of the six participating teachers believed that that peer correction impacted on students' writing performance in term of organization of letters. This view is illustrated in the following extracts.

[...] About letter writing, I think one of the most important aspects is the structure of a letter. Students don't often make errors about that, but when they correct in peers they can read their peers' writing and consider whether they provide enough parts of a letter or not. (Thuy, interview extract)

The structure of a letter usually includes three main parts: opening, body and salutation. When students correct in peers, they can self-recognize whether their writing performance has provided enough those parts." (Trang, interview extract)

I think when students correct their friends' letters, they can self-recognize which parts of a letter they don't have, and they also know which one(s) their friends' letter lacks" (Kha, interview extract)

\section{Language use}

Five out of the six participating teachers held the belief that that peer correction had the impact on the language use in students' letter writing performance. These extracts below are examples that illustratetheir views:

I personally think that students can find and correct the errors of grammar such as tenses and rules for verbs in their peers' writing. Then, they can minimize that kind of errors in their letters writing. (Nhu, interview extract)

When they exchange their writing work to each other, students can know that which errors of grammar their friends make. And they can avoid those errors when they write their own letters. (Linh, interview extract)

Both peer readers and writers can recognize the errors of grammar such as tenses especially, past simple tenses. When they correct these errors, they gradually improve their letter writing by avoiding those errors" (Thuy, interview extract)

In contrast to those, Thuy did not completely agree that peer correction can have the impact on the language use. She reported:

[...] About the impact of this technique on the language use, I think it is not really effective. I mean students may recognize that kind errors from their peers but they still tend to make that kind of errors latter. (Thuy, interview extract)

\section{Vocabulary}

Five out of the six participating teachers reported that peer correction had the impact on the vocabulary in students' letter writing performance. The following extracts illustratetheir views.

In my opinion, it helps students learn vocabulary from their friends' writing when they correct in peers. It is more helpful to those students who don't have much vocabulary to complete their letter. (Thuy, interview extract)

Students can improve their word choice. It means they can choose and use suitable words in their writing. (Nhu, interview extract)

[...] I believe students will learn from their friends' errors in term of word forms like verbs, adjectives, or nouns. They can use them better and more appropriately. Besides, they can learn new vocabulary from their peers. (Kha, interview extract) 
DOI: $10.51386 / 25815946 /$ ijsms-v4i3p112

Volume: 4 Issue: 3

May to June 2021

www.ijsmsjournal.org

\section{E. Mechanics}

Finally, three out of six participating teachers believed that this technique could have the impact on mechanics. Examples of these views are presented below.

As I said, students make many errors of spelling in their letter writing. For example, they write the word "help" without "l". Through this activity, when their friends correct that kind of errors, they will note it and improve it" (Thuy, interview extract)

I believed students can minimize the errors of spelling and punctuation in their letter writing. For example, they often put a full stop (dot) before the word "because" when they connect two clauses. (Nhu, interview extract)

For me, students can improve the mechanics in their letter writing, because my students easily find this kind of errors in their friends' writing. I mean students can avoid the errors of punctuation and spelling through peer correction. (Kha, interview extract)

\section{Discussion}

This study indicates that the participating teachers held positive beliefs about the impact of students' peer correction at the post-writing stage in letter writing. The followingsection discusses the findings from this study in relation to the research question.

\section{Research Question: What are teachers' beliefs about the impact of students' peer correction at the post- writing stage on students' writing performance in letter writing?}

The findings from the questionnaire and interview data show that students' peer correction was viewed as an activity in which students read, correct and give feedback on their friends' writing performance to each other. This is supported in the literature (Hyland, 2005; Trahasch, 2004). These authors claimed that peer correction is a collaborative activity in which students read, criticize and provide feedback to what other students' writing assignments for the sake of promoting writing performance.

With respect to the importance of students' peer correction in writing, the questionnaire data reveal that most of the teachers believed that peer correction could enable students to sharpen their critical thinking. This finding is consistent with prior studies by Kunwongse (2013) who claimed that students are able to sharpen their critical thinking abilities through this activity. Moreover, students' peer correction was believed to stimulate students' participation in their writing. Besides, it was found that students' peer correction could allow for autonomous learning in writing. This finding is in line with previous studies (Kunwongse, 2013; H. T. Nguyen, 2016), which indicated that peer correction had a significant impact on the development of the autonomy of EFL learners. Moreover, students' peer correction was believed to assist students in improving their own writing skills. This is consistent with other studies(Nelson \& Murphy, 1993; H. T. Nguyen, 2016) which addressed that peer correction can help learners develop their writing skills. It is interesting to note that this finding is not in line with the findings of a study by Shulin (2013) who claimed that EFL teachers may be unaware of the importance of peer feedback for their students' learning, which prevents students from engaging in and benefiting from peer interactions in L2 writing.

With regard to teachers' beliefs about the impact of students' peer correction at post-writing stage in letter writing, the findings reveal that the participating teachers had positive beliefs. This finding is consistent with prior studies (Behin \& Hamidi, 2011; H. T. Nguyen, 2016). A possible explanation for this finding is that the teachers believed that students' peer correction could offer students an opportunity to get new ideas that they haven't thought before for their own writing. Peer correction will assist students in exchanging ideas for their writing (Lee, 1997). As mentioned earlier, the findings alsoshown that peer correction affects students' writing ability. Students profited their letter writing from peer feedback by reducing errors. The findings from the questionnaires and interviews indicate that students' peer correction, in general, was believed to have the impact on five writing aspects in students' letter writing performance: Content, Language use, Organization, Vocabulary, and Mechnics. Therefore, students' peer correction was believed to help students improve their 
DOI: $\underline{10.51386 / 25815946 / i j s m s-v 4 i 3 p 112}$

Volume: 4 Issue: 3

May to June 2021

www.ijsmsjournal.org

writing performance in letter writing. This finding is in line with prior studies in the literature (e.g., Huisman, Saab, van Driel, \& van den Broek, 2018; Wahyuni, 2018) which highlighted that peer correction can help students increase their writing ability and performance.

\title{
6. Conclusions
}

The findings of this study provide insights into teachers' beliefs about the impact of students peer correction on their writing performance. In light of these findings, some pedagogical implications are drawn.

Firstly, as far as teachers' beliefs about the impact of peer correction on students' writing performance at the post writing stage in letter writing are concerned, it was found that teachers held positive beliefs about its impact on students' letter writing performance. This finding indicates that peer correction is believed as a useful activity in writing classroom. Therefore, teachers or instructors should create opportunities for students who give peer corrections to what others have written.

Secondly, teachers should carefully assess their students' level of language proficiency in order to encourage them to use peer correction on a regular basis. In addition, it is suggested that educational leaders and policy makers should make necessary changes or support to motivate both teachers and students to use this peer correction strategy in writing classes to help learners achieve best learning results.

Thirdly, it is recommended that students should use peer correction in addition to self and teacher correction in order to feel like active learners in the learning process. This gives them a sense of responsibility for their letter writing.Besides, peer correction should be conducted frequently to intensify the impact of this strategy on students' writing performance. It is expected that, with more regular practice of peer correction, all of the five aspects of students' letter writing such as Content, Vocabulary, Language Use, Mechanics and Organization can be improved.

\begin{abstract}
About the Authors
ToanBao Nguyen is a teacher of English and a manager at a foreign language center in Can Tho, Vietnam. He completed a bachelor's degree of English in Education in 2017. He is currently an MA student at Can Tho University. His research interests include writing skills and strategies, and teaching methodology. He is also keen on improving the learning experience for EFL students and applying innovative approaches for both young and adult learners.

HuanBuu Nguyen, is Associate Professor, School of Foreign Languages, Can Tho University, Vietnam. He received his doctoral degree at Massey University, New Zealand in 2014. His research focuses on teacher beliefs and changes in science education at a tertiary context. His research interests include action research, teacher change, language learning, ESP, and curriculum planning. He is now involved in writing teaching materials for ESP students at the university.
\end{abstract}

\section{References}

[1] Barton, D., \& Hall, N. (2000). Letter writing as a social practice. Philadelphia: John Benjamins Publishing Company.

[2] Behin, B., \& Hamidi, S. (2011). Peer correction: The key to improve the Iranian English as a foreign language learners' productive writing skill. Procedia Social and Behavioral Sciences, 30, 1057-1060. doi: DOI: 10.1016/j.sbspro.2011.10.206

[3] Bijami, M., Kashef, S. H., \& Nejad, M. S. (2013). Peer feedback in learning English writing: Advantages and disadvantages. Journal of Studies in Education, 3(4), 91-97.

[4] Boyatzis, R. E. (1998). Transforming qualitative information: Thematic analysis and code development Thousand Oaks, California: SAGE Publications, Inc.

[5] Cao, Y. H. (2012). Peer feedback in English writing: A case study in a Vietnamese context. (MA), Can Tho University, Can Tho.

[6] Creswell, J. W. (2014). Research design: Qualitative, quantitative, and mixed methods approaches (4nd Ed.). Thousand Oaks, California: SAGE Publications.

[7] Fan, Y., \& Xu, J. (2020). Exploring student engagement with peer feedback on L2 writing. Journnal of Second Language Writing, 50(4), 1-13. doi: http://dx.doi.org/10.1016/j.jslw.2020.100775 
DOI: $10.51386 / 25815946 /$ ijsms-v4i3p112

Volume: 4 Issue: 3

May to June 2021

www.ijssmsjournal.org

[8] Ferris, D. (2002). Treatment of error in second language student writing. Ann Arbor: University of Michigan Press.

[9] Fives, H., \& Gill, M. G. (2015). International handbook of research on teachers' beliefs. New York, NY: Routledge.

[10] Fraenkel, J. R., Wallen, N. E., \& Hyun, H. H. (2012). How to design and evaluate research in education (8th Ed.). New York: McGraw-Hill Humanities.

[11] Geyte, E. V. (2013). Writing learn to write better academic essays (Collins English for academic purposes). London: HarperCollins Publishers.

[12] Gielen, S., Tops, L., Dochy, F., Onghena, P., \& Smeets, S. (2010). A comparative study of peer and teacher peer feedback and of various peer feedback forms in a secondary school writing curriculum. British Educational Research Journal, 36(1), 143-162. doi: http://dx.doi.org/10.1080/01411920902894070

[13] Harmer, J. (2007). The practice of English language teaching (4th Ed.). Harlow, England: Pearson Longman.

[14] Huisman, B., Saab, N., van Driel, J., \& van den Broek, P. (2018). Peer feedback on academic writing: Undergraduate students' peer feedback role, peer feedback perceptions and essay performance. Assessment and Evaluation in Higher Education, 43(6), 955-968. doi: http://dx.doi.org/10.1080/02602938.2018.1424318

[15] Hyland, K. (2005). Second language writing. Cambridge: Cambridge University Press.

[16] Hyland, K., \& Hyland, F. (2006). Feedback in second language writing: Contexts and issues. Cambridge: Cambridge University Press.

[17] Jamoom, O. (2016). Teachers' beliefs and practices of feedback and preferences of students for feedback in university level EFL writing classrooms. $(\mathrm{PhD})$, University of Southampton.

[18] Kunwongse, S. (2013). Peer feedback, benefits and drawbacks. Thammasat Review, 16(3), 277-288.

[19] Lee, I. (1997). Peer reviews in a Hong Kong tertiary classroom. TESL Canada Journal, 15(1), 58-69.

[20] Liu, J., \& Hansen, J. (2002). Peer response in second language writing classrooms. Ann Arbor: University of Michigan Press.

[21] Min, H. T. (2006). The effects of trained peer review on EFL students' revision types and writing quality. Journal of Second Language Writing, 15(2), 118-141. doi: http://dx.doi.org/10.1016/j.jslw.2006.01.003

[22] Nelson, G., \& Murphy, J. (1993). Peer response groups: Do L2 writers use peer comments in revising their drafts? TESOL Quarterly, 27(1), 135-142. doi: http://dx.doi.org/10.2307/3586965

[23] Nguyen, H. B. (2013). Beliefs about support for teacher change in English for Specific Purposes university classes. New Zealand Studies in Applied Linguistics, 19(2), 36-48.

[24] Nguyen, H. B. (2019, October 26-27). Teacher beliefs and their change process in ESP university classes. Paper presented at the 15th International Conference on Language, Education, Humanities and Innovation, London, UK.

[25] Nguyen, H. T. (2016). Peer feedback practice in EFL tertiary writing classes. English Language Teaching, 9(6), 76-91. doi: 10.5539/elt.v9n6p76

[26] Pajares, M. F. (1992). Teachers' beliefs and educational research: Cleaning up a messy construct. Review of Educational Research, 62(3), 307-332. doi: http://dx.doi.org/10.3102/00346543062003307

[27] Pham, M. K. P. (2015). Elementary learners' attitudes towards peer correction in English writing at VUS center. (MA), University of Social Sciences and Humanities, Ho Chi Minh City.

[28] Richards, J. C., \& Renandya, W. A. (2002). Methodology in language teaching: An anthology of current practice. Cambridge: Cambridge University Press.

[29] Rivers, W. M. (2018). Teaching foreign language skills. Cambridge, Massachusetts: University of Chicago Press.

[30] Rokeach, M. (1968). Beliefs, attitudes, and values: A theory of organization and change. San Francisco: Jossey-Bass.

[31] Rollinson, P. (2005). Using peer feedback in the ESL writing class. ELT Journal, 59(1), 23-30. doi: http://dx.doi.org/10.1093/elt/cci003

[32] Schmitt, N. (2010). An introduction to applied linguistics. London: Holdden Education. 
DOI: $10.51386 / 25815946 /$ ijsms-v4i3p112

Volume: 4 Issue: 3

May to June 2021

www.ijsmsjournal.org

[33] Seidman, H. (2004). Relationship between instructors' beliefs and teaching practices for critical thinking in higher education (PhD), Concordia University, Montreal, Quebec, Canada.

[34] Sultana, A. (2009). Peer correction in ESL classrooms. BRAC University Journal, 6(1), 11-19.

[35] Topping, K. J. (2003). Self- and peer assessment in school and university: Reliability, validity and utility. In M. Segers, F. Dochy \& E. Cascallar (Eds.), Optimizing new modes of assessment: In search of qualities and standards. Dordrecht: Kluwer Academic.

[36] Trahasch, S. (2004). From peer assessment towards collaborative learning. Paper presented at the 34th ASEE/IEEE Frontiers in Education Conference, Savannah, GA.

[37] Wahyuni, S. (2018). Peer correctin on writing quality of college students having different cognitive styles. Journal of Socio-religious Research, 12(2), 259-282. doi: dx.doi.org/10.18326/infsl3v12i2.259-282

[38] Yang, Y. F. (2010). Students' reflection on online self-correction and peer review to improve writing. Computers and Education, $55(3), 1202-1210$ 